\title{
Nutrient Timing: A Garage Door of Opportunity?
}

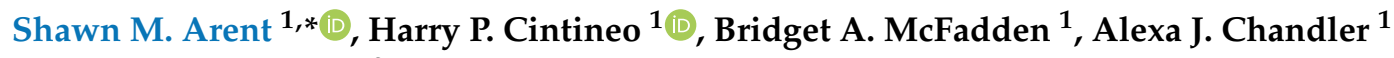 \\ and Michelle A. Arent ${ }^{2}$ \\ 1 Department of Exercise Science, University of South Carolina, Columbia, SC 29208, USA; \\ cintineo@email.sc.edu (H.P.C.); bm39@mailbox.sc.edu (B.A.M.); alexajc@email.sc.edu (A.J.C.) \\ 2 Department of Health Promotion, Education, and Behavior, University of South Carolina, \\ Columbia, SC 29208, USA; mgalardi@mailbox.sc.edu \\ * Correspondence: sarent@mailbox.sc.edu; Tel.: +1-803-576-8394
}

Received: 15 June 2020; Accepted: 28 June 2020; Published: 30 June 2020

\begin{abstract}
Nutrient timing involves manipulation of nutrient consumption at specific times in and around exercise bouts in an effort to improve performance, recovery, and adaptation. Its historical perspective centered on ingestion during exercise and grew to include pre- and post-training periods. As research continued, translational focus remained primarily on the impact and outcomes related to nutrient consumption during one specific time period to the exclusion of all others. Additionally, there seemed to be increasing emphasis on outcomes related to hypertrophy and strength at the expense of other potentially more impactful performance measures. As consumption of nutrients does not occur at only one time point in the day, the effect and impact of energy and macronutrient availability becomes an important consideration in determining timing of additional nutrients in and around training and competition. This further complicates the confining of the definition of "nutrient timing" to one very specific moment in time at the exclusion of all other time points. As such, this review suggests a new perspective built on evidence of the interconnectedness of nutrient impact and provides a pragmatic approach to help frame nutrient timing more inclusively. Using this approach, it is argued that the concept of nutrient timing is constrained by reliance on interpretation of an "anabolic window" and may be better viewed as a "garage door of opportunity" to positively impact performance, recovery, and athlete availability.
\end{abstract}

Keywords: exercise; sports; performance; recovery; adaptation; nutrition

\section{Introduction}

Nutrient timing is a dietary strategy in which specific nutrients are ingested at certain times surrounding training in order to bolster acute performance and/or chronic adaptations [1]. Much of the early research on this topic assessed the role of acute carbohydrate $(\mathrm{CHO})$ ingestion on exercise performance and rates of glycogen resynthesis to offset glycogen utilization and depletion that occurs particularly during moderate- and high-intensity aerobic exercise [2-6]. Following this work, researchers began investigating the role of acute protein (PRO) ingestion on performance, recovery, and adaptation following both endurance and resistance exercise. However, very few chronic interventional studies have assessed the role of nutrient timing on outcome variables related to performance, recovery, and adaptation. Instead, these early studies coupled with established acute bioenergetic, biochemical, and endocrine responses to exercise were used by Ivy and Portman [7] to provide a theoretical rationale for the role of nutrient timing in chronic adaptations to training.

During a bout of exercise, hormonal fluctuations occur in an intensity-dependent manner to induce various physiological (i.e., increase heart rate and contractility, increase blood flow to working muscles, etc.) and metabolic (i.e., activation of glycolytic and lipolytic enzymes) responses [8]. Hormones 
including insulin and its counter-regulatory hormones (i.e., glucagon, epinephrine, norepinephrine, cortisol, growth hormone, etc.) exhibit perturbations during exercise. In general, insulin shows a marked decrease, while the secretion of counter-regulatory hormones increases. These changes are metabolically critical for the maintenance of glucose homeostasis and for activating enzymes responsible for increasing mobilization and oxidation of fuels stored within the muscle (i.e., glycogen and intramuscular triglycerides) and throughout the body (i.e., liver glycogen and adipocyte-stored triglycerides). Additionally, independent of insulin, skeletal muscle contraction and the presence of metabolic byproducts stimulate the translocation of GLUT4 to the sarcolemma to further aid in glucose uptake in the muscle [9]. These actions also occur during long-duration, low-to-moderate-intensity exercise. Based on these physiological responses, Ivy and Portman [7] postulated that post-exercise feeding could be used to attenuate the large catabolic shift that occurs during exercise to favor a more anabolic state.

This post-exercise time period was seen to represent an opportunity to enhance adaptation and recovery though nutrition and became known as the "metabolic or anabolic window" due to the enhanced sensitivity of skeletal muscle to nutrient uptake and metabolism. This period was hypothesized to last approximately $45 \mathrm{~min}$ while GLUT4 activity remains elevated and glycogen synthase action increases even without stimulation by insulin [10]. This would provide for upregulation of glycogen replenishment. Additionally, in the absence of $\mathrm{CHO}$ availability during this period, the proteolytic action of cortisol results in the breakdown of muscle protein and release of alanine to serve as a substrate for gluconeogenesis and, ultimately, glycogen resynthesis [11]. Additionally, the role of protein intake during this period has been emphasized particularly in the context of resistance exercise as mechanical stress coupled with dietary protein or essential amino acids (EAA) alone, especially leucine, lead to significant increases in muscle protein synthesis (MPS) [12].

One of the most prominent nutrient timing studies on the role of muscular strength and hypertrophy was conducted by Cribb and Hayes [13]. They showed that a combined CHO and PRO supplement administered in a roughly 1:1 ratio (e.g., $32 \mathrm{~g}$ PRO and $34 \mathrm{~g} \mathrm{CHO}$ for an $80 \mathrm{~kg}$ individual) plus creatine monohydrate consumed both pre- and post-exercise resulted in greater strength and hypertrophy adaptations compared with consuming the same supplement in the morning and at night for 10 weeks in resistance-trained men. Future research used a similar design with regard to timing and outcome measures but did not include CHO in the supplement (42 g PRO only) [14]. No significant differences in performance or body composition were observed between groups. The dichotomous findings between these studies led researchers to believe post-exercise $\mathrm{CHO}$ may play a role in chronic strength and hypertrophy adaptations even though acute MPS does not appear to be potentiated with $\mathrm{CHO}$ inclusion [15]. While acute metabolic responses were not measured in these studies, the combined $\mathrm{CHO}$ and PRO supplement may have had a larger insulinogenic response and, although this hormone does not affect MPS, insulin has been shown to attenuate muscle protein breakdown in the post-exercise period [16]. This anticatabolic effect of insulin may have contributed to the significant differences in body composition changes between groups over the 10-week period in one study but not the other.

The existence of a post-exercise "anabolic window" has recently been called into question $[17,18]$. A 2013 meta-analysis assessing the role of protein timing on strength and hypertrophy was conducted in an attempt to synthesize the current research [19]. Although the primary finding was that protein timing did not appear to affect strength or hypertrophy outcomes, there are interesting methodological issues to consider. First, of the 23 studies that were included, only 4 studies included resistance-trained subjects. Second, subjects of the included studies came from a large variety of populations, including young men and women, elderly men and women, and older men and women with type 2 diabetes mellitus. Third, many of the studies included did not necessarily assess the role of protein timing but rather tested protein or amino acids alone versus placebo in the peri-exercise period. Lastly, as the authors pointed out, only 2 of the studies included in the analysis equated for total daily protein intake across both treatment and control groups. Conclusions regarding timing impacts would be tenuous at best in this case, particularly since the studies themselves were largely not timing studies. 
Furthermore, these results have been used to argue that nutrient timing is not important, when, in fact, only one nutrient (PRO) was included and other critical aspects of performance and recovery were not examined. Perhaps more importantly, this study points out the dearth of true nutrient timing studies that exist in trained athletes as well as the need to consider effects that go beyond just hypertrophy and strength.

While the concept of nutrient timing has previously been reviewed [1,20-26], this has often been done by focusing on singular time periods within the paradigm or organized based on macronutrient impacts rather than holistically as timing. As timing does not occur in isolation, coupled with the fact that the pre-, intra-, and post-training periods interact and influence each other, it is important to consider the concept of nutrient timing across a continuum. Additionally, much of the previous emphasis has been on strength and hypertrophy, despite the fact that athletic performance encompasses so much more than that. The purpose of this review is to present theoretical rationale, current evidence, and practical considerations for various nutrient timing strategies on performance and recovery in healthy, active adults, with a focus on trained athletes. This may help provide a new perspective on a pragmatic approach to maximize outcomes through nutritional intervention.

\section{Pre-Exercise Nutrition}

The pre-exercise nutritional window is often considered to be within approximately $<1 \mathrm{~h}$ of a training session, though studies have assessed the role of feeding up to $4 \mathrm{~h}$ prior to exercise [27]. The primary role of nutrient intake during this time is to ensure adequate fuel is available to the muscle during exercise to optimize performance. Within skeletal muscle, macronutrients, particularly fatty acids and $\mathrm{CHO}$, are required for producing adenosine triphosphate (ATP) to fuel the action of muscular contraction. Fatty acids are the primary fuel source at relatively low exercise intensities $\left(<60 \% \mathrm{VO}_{2 \max }\right)$ as the rate of energy utilization is not particularly high and the speed of ATP synthesis does not need to be extremely rapid [28]. The process of breaking down stored triacylglycerol molecules within adipose tissue (lipolysis via hormone-sensitive lipase), transporting free fatty acids (FFAs) to skeletal muscle mitochondria (intracellular shuttling via carnitine fatty-acyl transferases), oxidizing fatty acid chains into two-carbon molecules (acetyl-CoA), and ultimately, producing ATP via $\beta$ oxidation and the electron transport chain is a slower process and requires substantial blood flow to adipose tissue, making this possible at low but not high exercise intensities [29]. As exercise intensity increases, blood flow is progressively shunted away from adipose tissue via catecholamine-mediated vasoconstriction, while concomitantly, the rate of ATP utilization increases substantially. Thus, CHO, particularly in the form of muscle glycogen, plays an increasingly important role at higher exercise intensities.

FFA availability is seldom the limiting factor in exercise performance as humans have substantial stores of this substrate in adipose tissue [30]. However, $\mathrm{CHO}$ is stored in far lesser quantities throughout the body in the forms of liver (75-100 g or 300-400 kcal) and muscle glycogen (300-500 g or $1200-2000 \mathrm{kcal})$ and circulating glucose (15-20 g or 60-80 kcal), making glucose availability a limiting factor for work output capabilities [20]. These principles serve as the basis for trying to optimize pre-exercise nutrition through $\mathrm{CHO}$ intake. Early research has shown that $2 \mathrm{~h}$ of moderate-intensity and $1 \mathrm{~h}$ of high-intensity aerobic exercise can deplete muscle glycogen levels by up to 70\% [6]. Therefore, it is prudent to increase $\mathrm{CHO}$ intake during this period to maximize muscle glycogen levels prior to exercise. This guideline becomes even more important prior to high-intensity or long-duration exercise bouts.

A major concern often associated with pre-exercise $\mathrm{CHO}$ feeding is rebound hypoglycemia [31]. This occurs through the combined yet independent effects of insulin, which rises following the consumption of $\mathrm{CHO}$, and muscular contraction on glucose uptake into skeletal muscle via the translocation of GLUT4 to the sarcolemma, resulting in a decrease in circulating glucose. Research, however, shows that rebound hypoglycemia does not occur in all individuals and does not impede acute performance. In fact, the ergogenic effect of consuming additional $\mathrm{CHO}$ prior to training or competition 
appears to outweigh the risks associated with rebound hypoglycemia, and the hypoglycemic effect can be attenuated with a warm-up and small rest period before training or competition [32].

Initial studies on pre-exercise nutrition in sport, dating back to the 1930s, observed physiological responses during exercise following the ingestion of pre-exercise $\mathrm{CHO}$ in the form of glucose (GLU) and fructose (FRU) [33]. Soon after, researchers assessed the role of manipulating pre-exercise nutrition on exercise performance. Though Haldi and Wynn [34] showed no differences in performance following various nutritional strategies consisting of supplemental cane sugar in trained swimmers, this study opened the door for many more interventions on this topic. Hargreaves et al. [35] showed no benefit of $75 \mathrm{~g} \mathrm{CHO} \mathrm{(as} \mathrm{GLU} \mathrm{or} \mathrm{FRU} \mathrm{only)} 45$ min pre-exercise on time-to-exhaustion (TTE) performance or glycogen utilization at $75 \% \mathrm{VO}_{2 \mathrm{max}}$ in trained cyclists compared with placebo. However, a larger bolus of $\mathrm{CHO}$ (312 g) consumed $4 \mathrm{~h}$ pre-exercise resulted in an ergogenic effect on time trial (TT) performance at $70 \% \mathrm{VO}_{2 \max }$ following $100 \mathrm{~min}$ of cycling compared with placebo in recreationally trained cyclists, though the differences were not significant compared with energy-matched meals containing 45 or $156 \mathrm{~g} \mathrm{CHO}$ [36]. A subsequent study found significant improvements in a similar performance task when recreationally trained subjects consumed 1.1 or $2.2 \mathrm{~g} / \mathrm{kg} \mathrm{CHO} 1 \mathrm{~h}$ pre-exercise compared with placebo, though no differences were observed between the doses of $\mathrm{CHO}$ [37]. Pre-exercise $\mathrm{CHO}$ has also been found to affect substrate utilization during exercise. When $\mathrm{CHO}$ is consumed, glucose oxidation is favored over FFA even at low-to-moderate intensities $\left(\leq 60 \% \mathrm{VO}_{2 \max }\right)$ [38].

Overall, the effects of pre-exercise $\mathrm{CHO}$ feeding on endurance performance appear to be beneficial, though the results of some studies are equivocal. However, there are some methodological considerations that need to be considered when interpreting these findings. Major factors which are related and can impact the efficacy of pre-exercise feeding are the time since a previous exhaustive training session and current muscle glycogen content. It can be argued that the importance and ergogenic effects of pre-exercise $\mathrm{CHO}$ are highly dependent upon muscle glycogen content prior to that feeding. An individual with limited rest between training sessions and subsequently lower glycogen content likely has much more to gain from a pre-exercise $\mathrm{CHO}$ feeding than an individual who has rested for multiple days while consuming adequate $\mathrm{CHO}$ during that period. Another factor that may be affecting the efficacy of pre-exercise consumption of $\mathrm{CHO}$ is the task that is used to measure performance. For instance, time-to-exhaustion at $\leq 70 \% \mathrm{VO}_{2 \max }$ versus a time trial at $\geq 80 \% \mathrm{VO}_{2 \max }$ elicits different metabolic responses, with the latter requiring greater oxidation of $\mathrm{CHO}$. Therefore, the efficacy of pre-exercise $\mathrm{CHO}$ consumption is likely dependent on the task and intensity of exercise being performed.

Though much of the pre-exercise $\mathrm{CHO}$ feeding work has been done using aerobic modalities, it would also seem logical that high-intensity intermittent activities, such as resistance exercise, would benefit as well given their reliance on glycolytic, fast-twitch muscle fibers. These muscle fibers produce high levels of force through rapid muscular contraction, which is fueled by stored phosphagens (ATP and creatine phosphate), and anaerobic glycolysis, which produces lactate. However, total glycogen depletion of only about $40 \%$ has been documented following high-volume resistance exercise [39], suggesting that $\mathrm{CHO}$ availability is likely not a limiting factor unless glycogen stores are suboptimal to begin with. There is ample evidence demonstrating that pre-exercise CHO supplementation may attenuate reductions in glycogen even if it does not affect blood glucose [40]. Similar to the role of pre-exercise glycogen content mentioned previously, this suggests that performance may be improved by pre-exercise $\mathrm{CHO}$ feeding in those with low muscle glycogen content or who may train multiple times per day.

Another important factor to be considered is the modulation of post-exercise metabolic responses by pre-exercise feeding. Although muscle glycogen content does not appear to affect mammalian target of rapamycin (mTOR) pathway signaling and MPS [41], protein (PRO) consumption, particularly in the form of whey, during the pre-exercise period may bolster this post-exercise response [42]. This finding was not observed when only essential amino acids (EAA; $0.35 \mathrm{~g} / \mathrm{kg}$ FFM) in conjunction with $\mathrm{CHO}$ $(0.5 \mathrm{~g} / \mathrm{kg}$ FFM) were provided compared to placebo over a 2-h period [43]. However, when assessing the 
effects of timing, an EAA-CHO solution ( $6 \mathrm{~g}$ EAA, $35 \mathrm{~g}$ sucrose) consumed pre-exercise increased MPS to a greater extent than the same supplement consumed post-exercise [44]. Additionally, Dalbo et al. [45] showed that neither $\mathrm{CHO}$ nor PRO consumed pre-exercise augmented ubiquitin-proteasome pathway signaling, an indicator of muscle protein breakdown, in the post-exercise period. In a chronic study assessing the role of PRO timing in resistance-trained individuals over 10 weeks, pre- and post-exercise feedings elicited similar strength and hypertrophy changes when total PRO intake was matched between groups [46]. What has yet to be established is whether feedings in both timeframes would be more beneficial. To this point, much of the research has focused on an "either/or" approach to pre-exercise vs post-exercise nutrition.

Aside from performance, an often-overlooked benefit of pre-exercise nutrient intake is the impact on immune function in the context of both endurance and resistance exercise. Chen et al. [47] showed that high $\mathrm{CHO}$ pre-exercise meals $(104 \mathrm{~g} \mathrm{CHO})$ resulted in less disruption in immune cell counts and IL-6 in the 2-h post-exercise period compared to low $\mathrm{CHO}$ (56 g CHO). Differential effects on markers of immune function of supplemental $\mathrm{CHO}$ in not only the pre-exercise period but also intra- and post-exercise have been found [48]. However, it appears as though $\mathrm{CHO}$ offers more favorable impacts on salivary immunoglobulin A during high-repetition, high-volume resistance exercise compared to moderate-volume bouts. This is likely due to the immunosuppressive effects of hormonal responses that occur during high-intensity resistance exercise but do not occur at low intensities [49]. The beneficial effects on performance may be indirect in this case, as a healthier athlete may be more available for training and competition. Given the current global status and the SARS-CoV-2 pandemic, this is an effect that should not be overlooked but that has largely not been considered in previous reviews on nutrient timing.

The importance of pre-exercise nutrition is contingent on glycogen and energy status as well as the time since previous feeding. The timing of this pre-exercise meal becomes incredibly important for an individual who is glycogen-depleted and will be undergoing exercise that would typically require a high degree of glycogen contribution. Additionally, pre-training consumption of both $\mathrm{CHO}$ $(0.5-2.2 \mathrm{~g} / \mathrm{kg})$ and PRO $(0.3-0.35 \mathrm{~g} / \mathrm{kg})$ can aid not only in maximizing acute performance, but also in facilitating recovery and adaptation from that training. This likely depends on the quantity and timing of post-exercise protein intake as well.

\section{Intra-Exercise Nutrition}

The provision of $\mathrm{CHO}$ during activity is likely the most well-studied nutrient timing strategy, dating back to the 1960s [50]. CHO intake during the exercise can offset muscle and liver glycogen utilization and maintain blood glucose. This is especially important when exercise intensity is high, the duration exceeds $60 \mathrm{~min}$, or during shorter, supramaximal efforts [51,52]. In these scenarios, without adequate $\mathrm{CHO}$, exercise intensity will diminish [2] potentially due to lack of effective fuel, reduced calcium release from the sarcoplasmic reticulum, and fatigue [53].

Exogenous $\mathrm{CHO}$ oxidation rates increase exponentially during the first 75-90 min of exercise, indicating that $\mathrm{CHO}$ ingestion from the onset and throughout the exercise bout may aid in the sparing of muscle and liver glycogen [54]. However, large CHO intake in these conditions can create GI upset, which would be counterproductive to performance goals. It has been well established that maximum rates of oxidation of glucose (GLU) alone are $1 \mathrm{~g} / \mathrm{min}$, leading to roughly $60 \mathrm{~g} / \mathrm{h}$ [54]. However, ingestion of multiple types of $\mathrm{CHO}$ makes use of different transporters and results in an increased capability of $\mathrm{CHO}$ uptake and, thus, oxidation to roughly $1.5 \mathrm{~g} / \mathrm{min}$ or $90 \mathrm{~g} / \mathrm{h}$ [55]. Consumption of multiple transportable $\mathrm{CHO}$ not only results in increased $\mathrm{CHO}$ availability without GI upset [56] but may also improve performance [57]. In fact, an $8 \%$ higher power output was achieved during time trial following 120 minutes of steady state cycling when cyclists consumed 2:1 GLU:FRU beverages compared to consuming GLU alone [57]. It should be noted that FRU ingested at $1.2 \mathrm{~g} / \mathrm{min}$ combined with an equal quantity of GLU results in a higher CHO oxidation rate compared to ingestion of lesser quantities that would still meet the common $60 \mathrm{~g} / \mathrm{h}$ recommendations. This highlights the potential 
utility of higher intake rates of FRU and GLU to maximize CHO oxidation [55,58,59]. It is possible that recommendations for $\mathrm{CHO}$ consumption during exercise should be revisited based on these findings, as it appears higher rates, such as 90-144 g/h during long-duration events may be needed to maximize uptake via the unique glucose and fructose transporters [55,58-60]. Furthermore, ingestion of $120 \mathrm{~g} / \mathrm{h}$ of a 2:1 GLU:FRU solution during a mountain marathon was found to decrease markers of muscle damage as well as rating of perceived exertion (RPE) compared to consuming either 60 or 90 g/h [61], suggesting the positive effects of higher intakes go beyond just performance.

As our understanding of mechanisms underlying glycogen utilization and replenishment has grown, so too has the consideration of manipulation of $\mathrm{CHO}$ sources, ratios, and delivery methods in order to maximize the body's ability to absorb and utilize the substrates for fuel as a means to enhance acute and chronic performance over time [54]. A new CHO supplement composed of maltodextrin and FRU (1:0.8) in an alginate and pectin gel debuted to the general public during the chronicling of the efforts to break the 2-h marathon and had the sport supplement world buzzing with prospects of increasing $\mathrm{CHO}$ uptake and utilization. Proposal of the use of alginate, a derivative of seaweed, in an effort to encapsulate $\mathrm{CHO}$ to allow passage from the stomach to the small intestine without causing GI distress led to a proof-of-concept pilot study conducted in 16 well-trained Kenyan runners [62]. Four of the 16 runners were provided with $180 \mathrm{~g} / \mathrm{L}$ or $300 \mathrm{~g} / \mathrm{L} \mathrm{CHO}$ alginate gel while all athletes were provided with 40-50 g/L CHO every $5 \mathrm{~km}$, and supplements were consumed ad libitum. No reports of performance differences between athletes were indicated, however preliminary data from the pilot suggest that no GI issues resulted from ingestion of alginate-based $\mathrm{CHO}$. While measurement of $\mathrm{CHO}$ oxidation rates did not occur during the attempt to break the $2-\mathrm{h}$ marathon or the aforementioned pilot study, such research utilizing the unique $\mathrm{CHO}$ hydrogel with a concentration of $18 \%$ was conducted in elite cross-country skiers who performed a $2-\mathrm{h}$ exercise bout at 70\% $\mathrm{VO}_{2 \text { peak }}$ followed by a TT [63]. Results shows that compared to placebo, consumption of the hydrogel resulted in increased rates of exogenous $\mathrm{CHO}$ oxidation, decreased fat oxidation, and decreased usage of endogenous $\mathrm{CHO}$. Despite these findings, no performance differences were seen during $\mathrm{TT}$, potentially suggesting that $\mathrm{CHO}$ oxidation may have an "upper limit" in terms of performance impacts. However, speculation regarding the effectiveness of the glycogen depleting protocol has been noted, indicating additional research is required to determine the important of consumption of an 18\% CHO hydrogel on performance.

Another strategy to deliver $\mathrm{CHO}$ while minimizing GI distress and possibly further improve exercise performance is to co-ingest $\mathrm{PRO}$ and $\mathrm{CHO}$. A recent review and meta-analysis by Nielsen et al. [64] demonstrated favorable outcomes on performance during time trials or time to exhaustion efforts in groups consuming combined $\mathrm{CHO}-\mathrm{PRO}$ versus $\mathrm{CHO}$ alone. This effect remained when non-isocaloric supplements (CHO-PRO vs $\mathrm{CHO}$ alone) were consumed as well as when $\mathrm{CHO}-\mathrm{PRO}$ and $\mathrm{CHO}$ supplements were matched for $\mathrm{CHO}$ content. However, when investigating the effects of isocaloric supplementation of $\mathrm{CHO}-\mathrm{PRO}$ or $\mathrm{CHO}$ alone on time to exhaustion, no differences were seen [64]. While co-ingestion of PRO and $\mathrm{CHO}$ may not result in direct, acute performance improvements, indirect benefits include the ability to increase caloric consumption while decreasing CHO intake to avoid GI distress, the increase of amino acid (AA) bioavailability to decrease rates of muscle protein breakdown, the increased AA availability and utilization for gluconeogenesis, and even delay of central nervous system (CNS) fatigue [65]. The Central Fatigue Hypothesis suggests that as skeletal muscle selectively oxidizes branched chain amino acids (BCAAs) during prolonged exercise, free tryptophan crosses the blood-brain barrier increasing serotonin concentrations in the brain, which may lead to impaired exercise performance via central fatigue [66]. Consuming PRO during exercise alters the free tryptophan to BCAA ratio, resulting in decreased serotonin and delayed onset of central fatigue [66]. This may in part explain the findings of the meta-analysis by Stearns et al. [67], who concluded that PRO and CHO improved TTE but not TT performance. The authors speculate that TTE may rely on more psychological factors than a TT, such as boredom and lack of motivation, leading to the suggestion that there may be a CNS effect of PRO on endurance performance [67]. 
Preventing central fatigue and cognitive decline may be especially important during activities such as sporting matches, where decreases in blood glucose are related to impaired cognitive function $[68,69]$. This effect may be compounded by the fact that opportunities to consume $\mathrm{CHO}$ may be limited during these performances, further increasing the importance of maximizing initial glycogen stores and utilizing effective feeding strategies when possible during the match. Seminal work by Saltin [69] demonstrated intermittent, high-intensity activity lasting $>60 \mathrm{~min}$ results in diminished glycogen stores. When compared to pre-match levels, muscle glycogen was reduced by $67 \%$ at half-time and by $>90 \%$ upon the conclusion of a soccer match [69]. Glycogen depletion in these athletes is related to decreased concentration and mental acuity as well as increased fatigue [68,69]. Research demonstrates positive effects on cognition and improved performance under fatiguing conditions during prolonged sport matches as a result of pre-game and half-time feeding strategies [68,70]. Additionally, Russell et al. [71] found that $\mathrm{CHO}$ feeding during a simulated soccer match attenuated decrements in shooting performance and positively impacted blood glucose. Kingsley et al. [72] found that adding caffeine to a $\mathrm{CHO} /$ electrolyte gel improved sprint speed during a simulated soccer match compared to placebo, but it had less favorable impacts on hydration status than the $\mathrm{CHO} /$ electrolyte gel without the added caffeine. As with previous work, blood glucose was also favorably impacted. Notably, the sparing of liver glycogen plays an essential role in maintaining blood glucose levels and hepatic glucose output [11], ultimately ensuring adequate $\mathrm{CHO}$ is available for the brain to fuel cognitive processing [73]. Another often overlooked, but particularly important, benefit of $\mathrm{CHO}$ consumption during training is that it may also aid in reduction of immune suppression that can occur [74].

There is a persistent misconception that long-duration endurance events are primarily fueled by fat oxidation and, as such, would be better served by feedings or adaptions that would favor this rather than $\mathrm{CHO}$ feeding and oxidation. While investigations into ketone-fueled endurance events show promise that completion of such events is possible, direct comparison of $\mathrm{CHO}$ - versus ketone-fueled race-walking performances demonstrate advantage to those who are fueled by $\mathrm{CHO}[74,75]$. Support of "keto-adaptation" for athletic performance is often attributed to higher rates of fatty acid oxidation that occur in this state. However, the more pragmatic question to ask is if increased fat oxidation results in improved performance. Results from the aforementioned studies would suggest not. In fact, the increased fat oxidation that occurred during the exercise trial resulted in decreased exercise economy and a greater cost of performance to the athlete. Further, over the course of the 3-week intensified training protocol, the high-fat, low-CHO group was the only group that did not improve performance while the high- and periodized-CHO groups both demonstrated improved performance. For this strategy to yield benefit, exercise intensity must be appropriate for fat oxidation to occur, but contrary to popular thought, this is not always the case. Additionally, when in a "keto-adapted" state, the beneficial effects of supplemental $\mathrm{CHO}$ during exercise discussed throughout this section are attenuated as low- $\mathrm{CHO}$, high-fat diets decrease activity of the pyruvate dehydrogenase complex, the enzyme complex required to convert pyruvate to acetyl-CoA and initiate the complete aerobic oxidation of GLU [75].

Although not as substantial as endurance exercise lasting $>60 \mathrm{~min}$, resistance exercise can result in muscle glycogen depletion by $17-40 \%$ depending on the duration and intensity of the work bout $[76,77]$. Reduced muscular power and strength resulting from depleted muscle glycogen stores have led to recommendations for $\mathrm{CHO}$ consumption during resistance training as a means to increase blood glucose concentrations and reduce muscle glycogen depletion [39]. Overall, evidence suggests the largest ergogenic benefits of $\mathrm{CHO}$ consumption during resistance training will occur during high intensity exercise characterized by achieving repeated muscular failure and bouts where duration is $>40 \mathrm{~min}$ as these may have greater impacts on muscle glycogen depletion [39]. While consumption of $\mathrm{CHO}$ during a resistance training session has been shown to prevent muscle glycogen depletion, this may not translate to any improvement in performance metrics within the same training session [76]. However, consumption of $\mathrm{CHO}(3 \mathrm{~g} / \mathrm{kg})$ during a morning resistance training session has been 
shown to result in improved performance on number of sets-to-exhaustion for squat in a subsequent training session $4 \mathrm{~h}$ later [39]. While the acute performance benefits of $\mathrm{CHO}$ supplementation during resistance exercise may be limited to longer duration, high intensity work bouts, the positive impacts on subsequent training sessions cannot be ignored. This strategy may be of particular importance for athletes training multiple times per day. Additional benefits during the early recovery period may been seen as a result of $\mathrm{CHO}$ and PRO intake during training [39]. Research suggests that consuming PRO or branched-chain AAs (BCAAs) with $\mathrm{CHO}$ before or during resistance training can lead to greater MPS increases during the early post-exercise period compared to post-exercise supplementation [78]. Similarly, intra-workout CHO or EAA feedings have been found to positively impact hormonal responses and muscle protein degradation, but a combination of the two produced the greatest acute and chronic effects $[79,80]$.

Few studies have assessed application of within-session timing of $\mathrm{CHO}$ consumption., McConell, Kloot, and Hargreaves [81] found that when trained cyclists consumed $157.5 \mathrm{~g}$ CHO over the course of an entire exercise bout, as opposed to only within the final $30 \mathrm{~min}$, they improved 15-min TT performance following a $2-\mathrm{h}$ cycling bout at $70 \% \mathrm{VO}_{2 \text { peak }}$. As this study used a dosage $78.25 \mathrm{~g} / \mathrm{h}$ of a $21 \% \mathrm{CHO}$ beverage solution, which is larger than the current recommendations $(30-60 \mathrm{~g} / \mathrm{h}$ of 6-8\% CHO solution)its results inspired a follow-up study employing a similar design but with $75 \mathrm{~g}$ $(50 \mathrm{~g} / \mathrm{h})$ of a $6 \% \mathrm{CHO}$ beverage [82]. This follow-up study found improved TT performance following a 2-h cycling bout when $75 \mathrm{~g} \mathrm{CHO}$ was ingested using a front-loading (every 15 min during first hour) protocol compared to a continuous loading (every 15 min throughout the bout), or back-loading (every 15 min during second hour) protocol [81]. It may be hypothesized that differences are due in part to spared endogenous $\mathrm{CHO}$ during the front-loading protocol, while consumption of $75 \mathrm{~g}$ after partial glycogen depletion may not be sufficient to offset additional glycogen depletion or drop in blood glucose. Consumption of $75 \mathrm{~g} \mathrm{CHO}$ over the course of $2 \mathrm{~h}$ is on the lowest end of the current recommendations and is likely inadequate to offer benefit. Together, these data lend support to the need to revisit within-exercise $\mathrm{CHO}$ consumption recommendations.

The efficacy of intra-exercise nutrition, particularly $\mathrm{CHO}$, is highly dependent on pre-exercise feeding, glycogen status, and the type of exercise. For aerobic exercise lasting $\geq 2 \mathrm{~h}$, consumption of 90-144 g/h CHO in the form of a 2:1 GLU:FRU solution appears to maximize CHO uptake and oxidation while also sparing muscle glycogen. This becomes extremely important during competition, as long endurance bouts typically conclude with a sprint to the finish line. This relies heavily on anaerobic metabolism and the oxidation of endogenous muscle glycogen. Thus, sparing this fuel source throughout the bout becomes critical.

\section{Post-Exercise Nutrition}

The post-exercise period is often associated with temporary increases in fatigue and muscle soreness, and decrements in performance. During this time, catabolic processes predominate resulting in elevated cortisol and catecholamines, low insulin, reduced glycogen and substrate availability, and increased rates of muscle protein breakdown [20]. Post-exercise CHO and PRO intake have the ability to increase blood glucose levels, decrease cortisol, and increase substrate availability, thus amplifying the body's shift from a catabolic to a more anabolic state [20]. In addition, the activation of muscle GLUT4 transporters, increased glycogen synthase activity, and enhanced insulin sensitivity increase the responsiveness of skeletal muscle to $\mathrm{CHO}$ and AA uptake $[83,84]$. Therefore, the period following exercise provides an ideal opportunity for timed nutrient intake in order to promote the restoration of muscle glycogen and protein synthesis, while helping to reduce muscle protein breakdown $[20,83,85]$. In doing so, post-exercise nutrient timing may be an essential aspect of an optimal training program as it has the potential to improve the rate of recovery and maximizes training adaptations.

During exercise of moderate-to-high intensity, muscle glycogen stores represent the most important fuel source to sustain exercise. In these scenarios, post-exercise nutrient timing should largely focus on the restoration of muscle glycogen to improve rates of recovery. When exercise stops, the increase 
in post-exercise glucose transporters begins to decline and returns to baseline levels within $2 \mathrm{~h}$ [86]. The upregulation of GLUT4 transporters immediately following exercise provides a window of opportunity to take advantage of the muscle's ability to uptake glucose and optimally replenish glycogen stores. It has been suggested that an optimal restoration of muscle glycogen post-exercise can occur through $\mathrm{CHO}$ intakes of $1.0-1.5 \mathrm{~g} / \mathrm{kg} / \mathrm{h}[83,87,88]$ initiated within the first $2 \mathrm{~h}$ after the cessation of exercise [3], and should continue for 4 to 6 hours with more frequent feedings (15-30 min intervals) being favorable for maximal glycogen resynthesis $[83,84,89]$. In addition, high glycemic index (GIx) CHO may be optimal for rapid muscle glycogen resynthesis $[90,91]$ as they have been shown to produce a higher insulinemic response than low GIx CHO [92]; however, mixed results have been found regarding the effects of high GIx CHO on subsequent performance bouts $[92,93]$. It important to note that nutrient timing post-exercise is highlighted by the need to restore glycogen levels and becomes increasingly important when rapid restoration of glycogen is required, as such with multiple bout competitions or when insufficient $\mathrm{CHO}$ are being delivered to meet the daily energy goals [94]. It may not be as essential when $\mathrm{CHO}$ intake is sufficient to match energy demands [94]. However, timed ingestion of post-exercise $\mathrm{CHO}$ has never been shown to have negative implications on performance. It may also be crucial for athletes with a demanding training schedule over the course of the week, as well as for those training multiple times per day.

In addition to the beneficial effects of $\mathrm{CHO}$ to optimize glycogen stores, $\mathrm{CHO}$ intake accompanying exercise has been shown to attenuate various markers of muscle breakdown and cytokine production, thus improving inflammatory recovery $[48,95,96]$. The immunoprotective properties of CHO may be important during times of high-intensity or long-duration exercise which has been shown to suppress the immune system $[49,95,96]$, leaving an athlete susceptible to illness. Rapid ingestion of CHO post-exercise may aid in restoring the immune system, particularly after high-intensity or strenuous exercise. As previously noted, this has important ramifications for athlete availability for training and competition and has particular relevance in the current climate of the SARS-CoV-2 pandemic.

While $\mathrm{CHO}$ intake post-exercise plays a key role in glycogen resynthesis and immune protection, $\mathrm{PRO}$ is another macronutrient essential to post-exercise recovery. The co-ingestion of PRO and $\mathrm{CHO}$ has been shown to further increase insulin secretion leading to increased muscle glycogen synthesis $[83,89,97]$. The addition of PRO $(0.4 \mathrm{~g} / \mathrm{kg} / \mathrm{h})$ to $\mathrm{CHO}$ may stimulate glycogen synthesis to a greater extent than $\mathrm{CHO}$ alone, specifically if CHO intake is $<1.0-1.2 \mathrm{~g} / \mathrm{kg} / \mathrm{h}[83,89,98]$. PRO $(0.4 \mathrm{~g} / \mathrm{kg} / \mathrm{h})$ combined with $\mathrm{CHO}(0.8 \mathrm{~g} / \mathrm{kg} / \mathrm{h})$ within $2 \mathrm{~h}$ following exhaustive exercise has also been shown to improve subsequent cycling performance compared to $\mathrm{CHO}$ intake alone in endurance-trained men, suggesting improved recovery and restoration of fuel stores [99]. This may become particularly relevant in situations in which it may be difficult to consume optimal $\mathrm{CHO}$ amounts between multiple exercise bouts due to time constraints or GI problems, which may be a common concern with high $\mathrm{CHO}$ intakes [100]. Additional consideration for other forms of supplementation may also be warranted to improve glycogen resynthesis. For example, adding $2 \mathrm{mg} / \mathrm{kg} / \mathrm{h}$ caffeine to $1.0 \mathrm{~g} / \mathrm{kg} / \mathrm{h} \mathrm{CHO}$ intake over a $4-\mathrm{h}$ post-exercise period has further shown to increase glycogen synthesis rate by $66 \%$ compared to $\mathrm{CHO}$ alone [101], with additional improvements in subsequent high-intensity interval running capacity shown in recreationally active men ingesting $1.2 \mathrm{~g} / \mathrm{kg} \mathrm{CHO}$ with $8 \mathrm{mg} / \mathrm{kg}$ caffeine [102].

In addition to glycogen synthesis, PRO and EAA following exercise play a critical role in stimulating MPS and allow for skeletal muscle reconditioning [103]. The post-exercise period is characterized by increased muscle damage and protein breakdown [20,83]. Further, glycogen depletion increases the rate of protein degradation as AAs may undergo gluconeogenesis and be used to restore glycogen levels [104]. Therefore, protein intake post-exercise is critical to reduce protein breakdown and help to repair muscle damage [103]. With regard to stimulating MPS, rapidly-digestible, high-quality proteins containing sufficient EAAs may be more efficient compared to lower-quantity branched chain amino acids (BCAA) or slower digested proteins [105]. The exact amount of PRO required for optimal MPS post-exercise is unclear as this may depend on the athlete as well as the exercise session. PRO doses of $20 \mathrm{~g}$ from a high-quality, fast-absorbing source have been shown to maximize MPS following 
resistance exercise [106,107] and high-intensity aerobic exercise [108]. However, a follow-up study by MacNaughton and colleagues [109] compared 20 versus $40 \mathrm{~g}$ of whey PRO following whole-body resistance exercise in resistance trained young men and found $40 \mathrm{~g}$ stimulated MPS to a greater extent, highlighting the influence of the training session itself and the need for amino acid delivery. It is important to note that $\mathrm{CHO}$ intakes post-exercise have been shown to attenuate muscle protein breakdown but have not been shown to affect MPS [83,110,111].

Although post-exercise PRO plus leucine supplementation has been shown to saturate BCAA metabolism and decrease tissue damage, the effects on subsequent intense endurance performance were found to be trivial leading to the conclusion that post-exercise supplementation may be inconsequential when daily PRO consumption is sufficient to induce positive nitrogen balance [112]. It has also been suggested that the timing of protein intake post-exercise may not be important to maximizing MPS, as total PRO intake is more important than post-workout timing per se for strength and hypertrophy [17]. The fact that exercise-induced MPS is elevated for $24-48 \mathrm{~h}$ following high-intensity aerobic [113] and resistance exercise [114] has been used to bolster this position and argue that an "anabolic window" does not truly exist [19]. However, this fails to acknowledge that this larger window actually represents an opportunity to enhance the effectiveness of multiple feedings. Given the beneficial effects of protein to restore net protein balance post-exercise as well as the beneficial effects on glycogen synthesis, it appears there are advantages to PRO timing immediately post-exercise. The bottom line is that quality of training and total PRO intake in a day are more important than acute post-workout protein ingestion for strength and hypertrophy, but this becomes more of a hierarchy issue. Once training quality and total PRO intake are both accounted for, PRO timing may provide the added support to optimize performance. Even if it provides only small benefits, this may be an important training consideration for competitive athletes looking to optimize performance. In novice training populations which tend to be overrepresented in this literature, the effects may be far less impactful.

Ultimately, optimal post-exercise nutrition will largely depend on the type of exercise and the intensity, duration, and frequency of the exercise bouts. The magnitude of the training stimulus and resultant glycogen depletion and protein breakdown becomes particularly important for athletes who are required to perform multiple sessions per day. Therefore, feeding between sessions becomes increasingly important to ensure sufficient fuel stores for the subsequent exercise bout and overall recovery and adaptation. Both the intensity and duration of training will also influence the importance of timing as well as the nutrients needed for optimal responses. For those undergoing glycogen-depleting exercise, $1.0-1.5 \mathrm{~g} / \mathrm{kg} / \mathrm{h} \mathrm{CHO}$ for $4-6 \mathrm{~h}$ following exercise or the combination of $0.4 \mathrm{~g} / \mathrm{kg}$ PRO when $\mathrm{CHO}$ intake is $<1.0 \mathrm{~g} / \mathrm{kg} / \mathrm{h}$ appears to maximize glycogen replenishment, attenuate MPB, and optimize recovery. Following resistance exercise, $\geq 40 \mathrm{~g}$ PRO has been suggested to maximize MPS rates and reduce MPB although the exact amount will largely depend the individual as well as the exercise bout. The addition of $0.5 \mathrm{~g} / \mathrm{kg} \mathrm{CHO}$ also appears to be beneficial during this time to further reduce MPB.

\section{Additional Timing Considerations}

Early nutrient timing research on the efficacy of consuming specific nutrients surrounding an exercise bout has emphasized the importance of the peri-exercise time period. However, the remaining hours of the day comprise of the majority of the day, and nutrient intake during this time cannot be ignored. Fueling consistently throughout the day has been shown to be an effective strategy for maximizing performance at later times. For instance, although strategies such as skipping breakfast or time-restricted feeding may be effective for inducing weight loss [115,116], training in a fasted state results in worsened performance, particularly during prolonged exercise, compared to training in a fed state $[117,118]$. Further, omitting breakfast has been shown to attenuate performance in recreationally active adults even after lunch has been consumed [119].

Within the context of protein intake, performance, and body composition, the idea of protein pacing has been researched extensively in both overweight and obese individuals [120-122] as well as healthy, fit individuals [123]. Protein pacing refers to the concepts of continuously and consistently 
feeding PRO throughout the day in order to maintain maximal MPS rates and optimize recovery, adaptation, and performance. Though few data exist on the application of this strategy in athletes, this strategy is supported by detailed studies in healthy adults investigating protein consumption throughout the day in a balanced manner (spread evenly across meals at $30 \mathrm{~g} / \mathrm{meal}$ ) or in a skewed manner (10 $\mathrm{g}$ at breakfast, $15 \mathrm{~g}$ at lunch, $65 \mathrm{~g}$ at dinner) revealed increased protein synthesis in the groups consuming evenly distributed protein [124]. Additionally. work done by Arciero and colleagues [125] demonstrated that protein consumption evenly distributed in 6 meals throughout the day had significantly greater impact on metabolic markers than did the consumption of the same amount of protein consumed in 3 meals thought the day. It should be highlighted that the improvement in cardiometabolic markers were accompanied by increases in lean mass and drops in body fat and abdominal fat, while bodyweight remained unchanged [125]. In essence, the positive impact of evenly spaced protein consumption throughout the day was independent of weight loss.

Additionally, research on the ingestion of protein prior to sleep has suggested that this strategy is effective in maximizing overnight MPS rates, facilitating recovery and adaptation during this period $[126,127]$. Nighttime feeding of PRO and CHO in the form of chocolate milk has also been shown to affect morning metabolism, though subsequent day time trial time was not improved compared to placebo [128]. Comparing the efficacy of morning versus nighttime feeding of $56 \mathrm{~g}$ PRO from casein, however, showed no differences in muscular strength or endurance over 8 weeks of resistance training when subjects were consuming PRO in the quantity of $2.6 \mathrm{~g} / \mathrm{kg} / \mathrm{day}$ [129]. In this scenario, it is unlikely that nighttime feeding would have an appreciable effect given the overriding importance of total daily intake. Perhaps in lesser total quantities, this approach may be more impactful. Despite these results, it is clear that timing the consumption of nutrients throughout the day may offer certain benefits, even if not directly impacting performance, above simply focusing on the peri-exercise period. There is even evidence that timing/order of nutrient intake within a meal can impact metabolic responses, blood glucose, and insulin [130], which may have implications for nutrient absorption.

Recently, the concept of periodized nutrition has been promoted. Using this model, dietary intake is altered throughout training micro-, meso-, and macrocycles [25]. This model helps bridge the gap between acute performance and chronic adaptations. This may also be a useful approach for athletes needing to lose weight for competition and to promote lean mass gains during certain training phases. This approach can also be extended to include the concept of "CHO-restricted" training. This involves intentionally training in a state of low $\mathrm{CHO}$ availability and glycogen levels. Though this may attenuate performance within the acute training bout, it has been shown to potentially bolster long-term adaptations [25,131]. Such adaptations include mitochondrial biogenesis, increased capillarization, and increased capacity for lipid oxidation [25], all of which may contribute to improved endurance performance. In other words, there may be scenarios where "optimal" fueling during training is not always desirable in order to produce "optimal" adaptations. However, a few words of caution are warranted here. First, the studies on this approach have been relatively short in duration and have not applied it as an "all the time" solution to training. It is generally limited to select training sessions per week, often consisting of the steady-state training sessions on a morning following a high-intensity glycogen depleting session [132]. Second, this has almost exclusively been studied in endurance athletes (i.e., cyclists or runners) or using an endurance exercise protocol [132]. The applicability to power-endurance and team-sport athletes should be questioned due to potential concerns over injury when explosive movements or contact are involved. Finally, performance has not consistently been found to be improved [132]. When it has been, the protocol typically involved PRO feeding prior to the CHO-restricted bout [132-134], which would still argue for the importance of nutrient timing.

\section{Practical Implications}

What has often been interpreted as lack of support for the importance of nutrient timing has largely been based on studies in novice training populations and "non-timing" studies, or on noted equivocal findings. However, the equivocal nature of these findings is primarily due to the magnitude 
of an effect, not on complete absence of an effect or, more importantly, negative effects. In trained individuals and athletes, the overriding conclusion that should be drawn from this body of literature is that there never appears to be a disadvantage associated with feeding appropriately at any time surrounding an exercise bout. Additionally, beneficial effects may manifest themselves over time due to recovery considerations. The greatest ability of an athlete is availability. Effects on immune function have received little attention in previous reviews on this topic. We must also be cognizant of the fact that "nutrients" are more than just one single macronutrient. It would be prudent for athletes to attempt to optimize nutrient timing based not only on what has been tested directly but also on our mechanistic understanding of physiological responses to exercise both in an acute and chronic sense. In addition, the peri-exercise period, particularly in athletes who train multiple times per day and have busy schedules outside of training, should be viewed as a window of opportunity to feed to get closer to one's individual daily energy and macronutrient goals. In many cases, if the peri-workout period is not utilized for feeding, it will be almost impossible for athletes and hard-training individuals to adequately hit their total daily intake needs.

Further, in the context of sports nutrition for optimizing performance and recovery, the issue of consuming nutrients should not be separated into "before, during, or, after" but should be combined as "before, during, and, after." Though research suggests that consuming certain nutrients at certain times may be more beneficial than other times, there is likely the most to gain from consuming nutrients at all times surrounding exercise bouts and throughout the day. As mentioned previously, this concept becomes most important once individuals have determined and consistently consumed adequate total energy and macronutrients throughout the day. Athletes, particularly those who train multiple times per day, participate in glycogen-depleting exercise during training and/or competition, and incur substantial amounts of muscular damage, should look at the peri-exercise period as well as the remaining times throughout the day as opportunities to consume nutrients such as $\mathrm{CHO}$ and $\mathrm{PRO}$ to help facilitate recovery, adaptation, and ultimately performance. Frequent and consistent $\mathrm{CHO}$ and PRO feedings appear to have notable positive benefits [12,123]. Examples of nutrient timing strategies for a power-endurance athlete, such as a soccer player, on match and training days can be found in Figure 1.

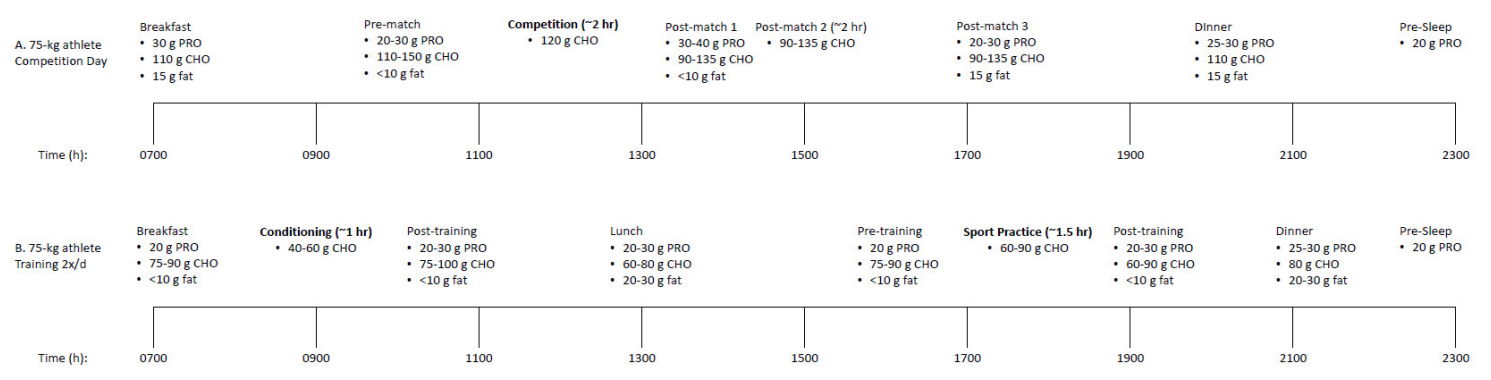

Figure 1. Sample nutrient timing strategy for a 75-kg power-endurance athlete (i.e., soccer) for (A) competition day and (B) conditioning session + team practice.

Macronutrient sources are also important to consider, particularly in the peri-workout period. Much of the research discussed thus far has provided high-glycemic, low-fiber, fast-absorbing carbohydrates (i.e., dextrose, maltodextrin, etc.) before, during and immediately post-exercise. These $\mathrm{CHO}$ sources allow for rapid GI transit time and gastric emptying to allow for rapid release into the blood and uptake by the muscle for oxidation or glycogen synthesis. Additionally, the role of protein supplementation has been recently reviewed [26], and it is clear that high-quality, fast-absorbing whey protein derived from dairy appears to be the most convenient protein source in the post-exercise period to maximally stimulate MPS. Whey protein also appears to stimulate post-exercise MPS to a greater extent than soy protein when consuming a protein-matched (30 g) dose [135], which remains consistent even when EAA content $(10 \mathrm{~g})$ is matched [107]. 
In conclusion, nutrient timing is a nuanced topic, and its importance is highly context dependent. The scenarios in which specific nutrient intake becomes important have been discussed throughout this review. For instance, if one's glycogen levels are low or depleted prior to training or competition, consuming $\mathrm{CHO}$ prior to exercise will have a much greater effect on acute performance than for an individual who has already sufficiently replenished glycogen. Additionally, the consumption of PRO immediately post-exercise is likely much more important for stimulating MPS and attenuating MPB for an individual who resistance-trained in a fasted state versus one who had a pre-exercise meal consisting of adequate $\mathrm{PRO}$ and $\mathrm{CHO}$. Ultimately, once individual total daily energy and macronutrient needs are assessed and determined, nutrient timing strategies can be implemented in accordance with the current evidence which shows that feeding consistently throughout the day, particularly in the peri-exercise period, is the most optimal strategy for maximizing performance. It is fair to question the nature of the "anabolic window" based on our current understanding of protein metabolism and the stimulus provided by resistance training. However, if anything, it would simply appear that this window is much longer than originally proposed and may in fact be more like a "garage door". Unfortunately, this has been used to argue that post-exercise refeeding is not essential. However, it may be optimal and represents an opportunity to improve adaptation and recovery. When it comes to nutrient intake for athletes and active individuals, there exists a hierarchy of needs. If we look at it like baking a cake, the training stimulus and the total daily intake form the cake itself. The timing of nutrient intake is more like the frosting, which requires the foundation of the cake to do its job. Finally, the more advanced concepts such as nutrient periodization and CHO-restricted training are the decorations on the cake. Most importantly, proper feeding around training, despite questions of magnitude of benefit, is never detrimental.

Author Contributions: Conceptualization, S.M.A.; Writing, S.M.A., H.P.C., B.A.M., A.J.C., and M.A.A. All authors have read and agreed to the published version of the manuscript.

Funding: This research received no external funding.

Conflicts of Interest: The authors declare no conflict of interest.

\section{References}

1. Kerksick, C.M.; Arent, S.; Schoenfeld, B.J.; Stout, J.R.; Campbell, B.; Wilborn, C.D.; Taylor, L.; Kalman, D.; Smith-Ryan, A.E.; Kreider, R.B.; et al. International society of sports nutrition position stand: Nutrient timing. J. Int. Soc. Sport Nutr. 2017, 14, 33. [CrossRef]

2. Karlsson, J.; Saltin, B. Diet, muscle glycogen, and endurance performance. J. Appl. Physiol. 1971, 31, 203-206. [CrossRef]

3. Ivy, J.L.; Katz, A.L.; Cutler, C.L.; Sherman, W.M.; Coyle, E.F. Muscle glycogen synthesis after exercise: Effect of time of carbohydrate ingestion. J. Appl. Physiol. 1988, 64, 1480-1485. [CrossRef]

4. Hawley, J.A.; Burke, L.M. Effect of meal frequency and timing on physical performance. Br. J. Nutr. 1997, 77 (Suppl. 1), S91-S103. [CrossRef]

5. Gollnick, P.D.; Armstrong, R.B.; Sembrowich, W.L.; Shepherd, R.E.; Saltin, B. Glycogen depletion pattern in human skeletal muscle fibers after heavy exercise. J. Appl. Physiol. 1973, 34, 615-618. [CrossRef]

6. Gollnick, P.D.; Piehl, K.; Saltin, B. Selective glycogen depletion pattern in human muscle fibres after exercise of varying intensity and at varying pedalling rates. J. Physiol. 1974, 241, 45-57. [CrossRef]

7. Ivy, J.L.; Portman, R.M. Nutrient Timing: The Future of Sports Nutrition; Basic Health Publications: Laguna Beach, CA, USA, 2004; p. 211.

8. Borer, K.T. Advanced Exercise Endocrinology; Human Kinetics: Champaign, IL, USA, 2012.

9. Richter, E.A.; Hargreaves, M. Exercise, GLUT4, and skeletal muscle glucose uptake. Physiol. Rev. 2013, 93, 993-1017. [CrossRef] [PubMed]

10. Ivy, J.L.; Kuo, C.H. Regulation of GLUT4 protein and glycogen synthase during muscle glycogen synthesis after exercise. Acta Physiol. Scand. 1998, 162, 295-304. [CrossRef] [PubMed]

11. Brooks, G.A.; Fahey, T.D.; Baldwin, K.M. Exercise Physiology: Human Bioenergetics and Its Applications, 4th ed.; McGraw Hill: New York, NY, USA, 2005. 
12. Atherton, P.J.; Smith, K. Muscle protein synthesis in response to nutrition and exercise. J. Physiol. 2012, 590, 1049-1057. [CrossRef]

13. Cribb, P.J.; Hayes, A. Effects of supplement timing and resistance exercise on skeletal muscle hypertrophy. Med. Sci. Sports Exerc. 2006, 38, 1918-1925. [CrossRef] [PubMed]

14. Hoffman, J.R.; Ratamess, N.A.; Tranchina, C.P.; Rashti, S.L.; Kang, J.; Faigenbaum, A.D. Effect of protein-supplement timing on strength, power, and body-composition changes in resistance-trained men. Int. J. Sport Nutr. Exerc. Metab. 2009, 19, 172-185. [CrossRef] [PubMed]

15. Koopman, R.; Beelen, M.; Stellingwerff, T.; Pennings, B.; Saris, W.H.; Kies, A.K.; Kuipers, H.; van Loon, L.J. Coingestion of carbohydrate with protein does not further augment postexercise muscle protein synthesis. Am. J. Physiol. Endocrinol. Metab. 2007, 293, E833-E842. [CrossRef]

16. Everman, S.; Meyer, C.; Tran, L.; Hoffman, N.; Carroll, C.C.; Dedmon, W.L.; Katsanos, C.S. Insulin does not stimulate muscle protein synthesis during increased plasma branched-chain amino acids alone but still decreases whole body proteolysis in humans. Am. J. Physiol. Endocrinol. Metab. 2016, 311, E671-E677. [CrossRef]

17. Aragon, A.A.; Schoenfeld, B.J. Nutrient timing revisited: Is there a post-exercise anabolic window? J. Int. Soc. Sport Nutr. 2013, 10, 5. [CrossRef] [PubMed]

18. Schoenfeld, B.J.; Aragon, A.A. Is there a postworkout anabolic window of opportunity for nutrient consumption? Clearing up controversies. J. Orthop. Sports Phys. Ther. 2018, 48, 911-914. [CrossRef] [PubMed]

19. Schoenfeld, B.J.; Aragon, A.A.; Krieger, J.W. The effect of protein timing on muscle strength and hypertrophy: A meta-analysis. J. Int. Soc. Sport Nutr. 2013, 10, 53. [CrossRef]

20. Ivy, J.L.; Ferguson-Stegall, L.M. Nutrient Timing. Am. J. Lifestyle Med. 2014, 8, 246-259. [CrossRef]

21. Burke, L.M.; Castell, L.M.; Casa, D.J.; Close, G.L.; Costa, R.J.S.; Desbrow, B.; Halson, S.L.; Lis, D.M.; Melin, A.K.; Peeling, P.; et al. International association of athletics federations consensus statement 2019: Nutrition for athletics. Int. J. Sport Nutr. Exerc. Metab. 2019, 29, 73-84. [CrossRef]

22. Bytomski, J.R. Fueling for performance. Sports Health 2018, 10, 47-53. [CrossRef]

23. Fritzen, A.M.; Lundsgaard, A.M.; Kiens, B. Dietary fuels in athletic performance. Annu. Rev. Nutr. 2019, 39, 45-73. [CrossRef]

24. Hector, A.J.; Phillips, S.M. Protein recommendations for weight loss in elite athletes: A focus on body composition and performance. Int. J. Sport Nutr. Exerc. Metab. 2018, 28, 170-177. [CrossRef] [PubMed]

25. Stellingwerff, T.; Morton, J.P.; Burke, L.M. A framework for periodized nutrition for athletics. Int. J. Sport Nutr. Exerc. Metab. 2019, 29, 141-151. [CrossRef] [PubMed]

26. Cintineo, H.P.; Arent, M.A.; Antonio, J.; Arent, S.M. Effects of protein supplementation on performance and recovery in resistance and endurance training. Front. Nutr. 2018, 5, 83. [CrossRef]

27. Ormsbee, M.J.; Bach, C.W.; Baur, D.A. Pre-exercise nutrition: The role of macronutrients, modified starches and supplements on metabolism and endurance performance. Nutrients 2014, 6, 1782-1808. [CrossRef]

28. McArdle, W.D.; Katch, F.I.; Katch, V.L. Exercise Physiology: Nutrition, Energy, and Human Performance; Lippincott, Williams, and Wilkins: Philadelphia, PA, USA, 2014.

29. Gropper, S.S.; Smith, J.L. Advanced Nutrition and Human Metabolism, 7th ed.; Cengage: Independence, KY, USA, 2018.

30. Burke, L.M. Re-examining high-fat diets for sports performance: Did we call the 'nail in the coffin' too soon? Sports Med. 2015, 45 (Suppl. 1), S33-S49. [CrossRef] [PubMed]

31. Jeukendrup, A.E.; Killer, S.C. The myths surrounding pre-exercise carbohydrate feeding. Ann. Nutr. Metab. 2010, 57 (Suppl. 2), 18-25. [CrossRef]

32. Brouns, F.; Rehrer, N.J.; Saris, W.H.; Beckers, E.; Menheere, P.; ten Hoor, F. Effect of carbohydrate intake during warming-up on the regulation of blood glucose during exercise. Int. J. Sports Med. 1989, 10 (Suppl. 1), S68-S75. [CrossRef] [PubMed]

33. Carpenter, T.M.; Fox, E.L. The effect of muscular work upon the respiratory exchange of man after the ingestion of glucose and of fructose. Arbeitsphysiologie 1931, 4, 532-569.

34. Haldi, J.; Wynn, W. Observations on efficiency of swimmers as related to some changes in pre-exercise nutriment. J. Nutr. 1946, 31, 525-532. [CrossRef]

35. Hargreaves, M.; Costill, D.L.; Fink, W.J.; King, D.S.; Fielding, R.A. Effect of pre-exercise carbohydrate feedings on endurance cycling performance. Med. Sci. Sports Exerc. 1987, 19, 33-36. [CrossRef] 
36. Sherman, W.M.; Brodowicz, G.; Wright, D.A.; Allen, W.K.; Simonsen, J.; Dernbach, A. Effects of 4 h preexercise carbohydrate feedings on cycling performance. Med. Sci. Sports Exerc. 1989, 21, 598-604. [CrossRef] [PubMed]

37. Sherman, W.M.; Peden, M.C.; Wright, D.A. Carbohydrate feedings $1 \mathrm{~h}$ before exercise improves cycling performance. Am. J. Clin. Nutr. 1991, 54, 866-870. [CrossRef] [PubMed]

38. Achten, J.; Jeukendrup, A.E. The effect of pre-exercise carbohydrate feedings on the intensity that elicits maximal fat oxidation. J. Sports Sci. 2003, 21, 1017-1024. [CrossRef]

39. Haff, G.G.; Lehmkuhl, M.J.; McCoy, L.B.; Stone, M.H. Carbohydrate supplementation and resistance training. J. Strength Cond. Res. 2003, 17, 187-196. [CrossRef]

40. Escobar, K.A.; VanDusseldorp, T.A.; Kerksick, C.M. Carbohydrate intake and resistance-based exercise: Are current recommendations reflective of actual need? Br. J. Nutr. 2016, 116, 2053-2065. [CrossRef]

41. Camera, D.M.; West, D.W.; Burd, N.A.; Phillips, S.M.; Garnham, A.P.; Hawley, J.A.; Coffey, V.G. Low muscle glycogen concentration does not suppress the anabolic response to resistance exercise. J. Appl. Physiol. 2012, 113, 206-214. [CrossRef]

42. Burke, L.M.; Hawley, J.A.; Ross, M.L.; Moore, D.R.; Phillips, S.M.; Slater, G.R.; Stellingwerff, T.; Tipton, K.D.; Garnham, A.P.; Coffey, V.G. Preexercise aminoacidemia and muscle protein synthesis after resistance exercise. Med. Sci. Sports Exerc. 2012, 44, 1968-1977. [CrossRef] [PubMed]

43. Fujita, S.; Dreyer, H.C.; Drummond, M.J.; Glynn, E.L.; Volpi, E.; Rasmussen, B.B. Essential amino acid and carbohydrate ingestion before resistance exercise does not enhance postexercise muscle protein synthesis. J. Appl. Physiol. 2009, 106, 1730-1739. [CrossRef]

44. Tipton, K.D.; Rasmussen, B.B.; Miller, S.L.; Wolf, S.E.; Owens-Stovall, S.K.; Petrini, B.E.; Wolfe, R.R. Timing of amino acid-carbohydrate ingestion alters anabolic response of muscle to resistance exercise. Am. J. Physiol. Endocrinol. Metab. 2001, 281, E197-E206. [CrossRef]

45. Dalbo, V.J.; Roberts, M.D.; Hassell, S.; Kerksick, C.M. Effects of pre-exercise feeding on serum hormone concentrations and biomarkers of myostatin and ubiquitin proteasome pathway activity. Eur. J. Nutr. 2013, 52, 477-487. [CrossRef] [PubMed]

46. Schoenfeld, B.J.; Aragon, A.; Wilborn, C.; Urbina, S.L.; Hayward, S.E.; Krieger, J. Pre-versus post-exercise protein intake has similar effects on muscular adaptations. PeerJ 2017, 5, e2825. [CrossRef]

47. Chen, Y.J.; Wong, S.H.; Wong, C.K.; Lam, C.W.; Huang, Y.J.; Siu, P.M. The effect of a pre-exercise carbohydrate meal on immune responses to an endurance performance run. Br. J. Nutr. 2008, 100, 1260-1268. [CrossRef] [PubMed]

48. Chan, M.A.; Koch, A.J.; Benedict, S.H.; Potteiger, J.A. Influence of carbohydrate ingestion on cytokine responses following acute resistance exercise. Int. J. Sport Nutr. Exerc. Metab. 2003, 13, 454-465. [CrossRef]

49. Kraemer, W.J.; Ratamess, N.A. Hormonal responses and adaptations to resistance exercise and training. Sports Med. 2005, 35, 339-361. [CrossRef] [PubMed]

50. Mager, M.; Iampietro, P.F.; Goldman, R.F. The effect of supplementary feeding on plasma free fatty acids during work. Metabolism 1964, 13, 823-830. [CrossRef]

51. Bergstrom, J.; Hermansen, L.; Hultman, E.; Saltin, B. Diet, muscle glycogen and physical performance. Acta Physiol. Scand. 1967, 71, 140-150. [CrossRef]

52. Vollestad, N.K.; Tabata, I.; Medbo, J.I. Glycogen breakdown in different human muscle fibre types during exhaustive exercise of short duration. Acta Physiol. Scand. 1992, 144, 135-141. [CrossRef]

53. Ortenblad, N.; Nielsen, J.; Saltin, B.; Holmberg, H.C. Role of glycogen availability in sarcoplasmic reticulum Ca2+ kinetics in human skeletal muscle. J. Physiol. 2011, 589, 711-725. [CrossRef] [PubMed]

54. Jeukendrup, A.E.; Jentjens, R. Oxidation of carbohydrate feedings during prolonged exercise: Current thoughts, guidelines and directions for future research. Sports Med. 2000, 29, 407-424. [CrossRef] [PubMed]

55. Jentjens, R.L.; Moseley, L.; Waring, R.H.; Harding, L.K.; Jeukendrup, A.E. Oxidation of combined ingestion of glucose and fructose during exercise. J. Appl. Physiol 2004, 96, 1277-1284. [CrossRef] [PubMed]

56. Cermak, N.M.; van Loon, L.J. The use of carbohydrates during exercise as an ergogenic aid. Sports Med. 2013, 43, 1139-1155. [CrossRef]

57. Currell, K.; Jeukendrup, A.E. Superior endurance performance with ingestion of multiple transportable carbohydrates. Med. Sci. Sports Exerc. 2008, 40, 275-281. [CrossRef] [PubMed]

58. Jentjens, R.L.; Jeukendrup, A.E. High rates of exogenous carbohydrate oxidation from a mixture of glucose and fructose ingested during prolonged cycling exercise. Br. J. Nutr. 2005, 93, 485-492. [CrossRef] 
59. Jeukendrup, A.E.; Moseley, L.; Mainwaring, G.I.; Samuels, S.; Perry, S.; Mann, C.H. Exogenous carbohydrate oxidation during ultraendurance exercise. J. Appl. Physiol. 2006, 100, 1134-1141. [CrossRef] [PubMed]

60. Hulston, C.J.; Wallis, G.A.; Jeukendrup, A.E. Exogenous $\mathrm{CHO}$ oxidation with glucose plus fructose intake during exercise. Med. Sci. Sports Exerc. 2009, 41, 357-363. [CrossRef]

61. Viribay, A.; Arribalzaga, S.; Mielgo-Ayuso, J.; Castaneda-Babarro, A.; Seco-Calvo, J.; Urdampilleta, A. Effects of $120 \mathrm{~g} / \mathrm{h}$ of carbohydrates intake during a mountain marathon on exercise-induced muscle damage in elite runners. Nutrients 2020, 12. [CrossRef]

62. Sutehall, S.; Muniz-Pardos, B.; Bosch, A.N.; Di Gianfrancesco, A.; Pitsiladis, Y.P. Sports drinks on the edge of a new era. Curr. Sports Med. Rep. 2018, 17, 112-116. [CrossRef]

63. Pettersson, S.; Edin, F.; Bakkman, L.; McGawley, K. Effects of supplementing with an $18 \%$ carbohydrate-hydrogel drink versus a placebo during whole-body exercise in $-5{ }^{\circ} \mathrm{C}$ with elite cross-country ski athletes: A crossover study. J. Int. Soc. Sport Nutr. 2019, 16, 46. [CrossRef]

64. Nielsen, L.L.K.; Lambert, M.N.T.; Jeppesen, P.B. The effect of ingesting carbohydrate and proteins on athletic performance: A systematic review and meta-analysis of randomized controlled trials. Nutrients 2020, 12. [CrossRef]

65. Betts, J.A.; Stevenson, E. Should protein be included in CHO-based sports supplements? Med. Sci. Sports Exerc. 2011, 43, 1244-1250. [CrossRef]

66. Davis, J.M.; Bailey, S.P. Possible mechanisms of central nervous system fatigue during exercise. Med. Sci. Sports Exerc. 1997, 29, 45-57. [CrossRef] [PubMed]

67. Stearns, R.L.; Emmanuel, H.; Volek, J.S.; Casa, D.J. Effects of ingesting protein in combination with carbohydrate during exercise on endurance performance: A systematic review with meta-analysis. J. Strength Cond. Res. 2010, 24, 2192-2202. [CrossRef]

68. Dardarian, N.; O'Donnell, K. Applying the science of nutrient timing and distribution on-and-off the soccer pitch: Sports nutritionist's experience. Curr. Sports Med. Rep. 2018, 17, 242-243. [CrossRef]

69. Saltin, B. Metabolic fundamentals in exercise. Med. Sci Sports Exerc 1973, 5, 137-146. [CrossRef]

70. Baker, L.B.; Nuccio, R.P.; Jeukendrup, A.E. Acute effects of dietary constituents on motor skill and cognitive performance in athletes. Nutr. Rev. 2014, 72, 790-802. [CrossRef] [PubMed]

71. Russell, M.; Benton, D.; Kingsley, M. Influence of carbohydrate supplementation on skill performance during a soccer match simulation. J. Sci. Med. Sport 2012, 15, 348-354. [CrossRef] [PubMed]

72. Kingsley, M.; Penas-Ruiz, C.; Terry, C.; Russell, M. Effects of carbohydrate-hydration strategies on glucose metabolism, sprint performance and hydration during a soccer match simulation in recreational players. J. Sci. Med. Sport 2014, 17, 239-243. [CrossRef] [PubMed]

73. Grego, F.; Vallier, J.M.; Collardeau, M.; Bermon, S.; Ferrari, P.; Candito, M.; Bayer, P.; Magnie, M.N.; Brisswalter, J. Effects of long duration exercise on cognitive function, blood glucose, and counterregulatory hormones in male cyclists. Neurosci. Lett. 2004, 364, 76-80. [CrossRef] [PubMed]

74. Gleeson, M. Immune function in sport and exercise. J. Appl. Physiol. 2007, 103, 693-699. [CrossRef] [PubMed]

75. Stellingwerff, T.; Spriet, L.L.; Watt, M.J.; Kimber, N.E.; Hargreaves, M.; Hawley, J.A.; Burke, L.M. Decreased $\mathrm{PDH}$ activation and glycogenolysis during exercise following fat adaptation with carbohydrate restoration. Am. J. Physiol. Endocrinol. Metab. 2006, 290, E380-E388. [CrossRef]

76. Haff, G.G.; Koch, A.J.; Potteiger, J.A.; Kuphal, K.E.; Magee, L.M.; Green, S.B.; Jakicic, J.J. Carbohydrate supplementation attenuates muscle glycogen loss during acute bouts of resistance exercise. Int. J. Sport Nutr. Exerc. Metab. 2000, 10, 326-339. [CrossRef]

77. Haff, G.G.; Schroeder, C.A.; Koch, A.J.; Kuphal, K.E.; Comeau, M.J.; Potteiger, J.A. The effects of supplemental carbohydrate ingestion on intermittent isokinetic leg exercise. J. Sports Med. Phys. Fit. 2001, 41, $216-222$.

78. van Loon, L.J. Is there a need for protein ingestion during exercise? Sports Med. 2014, 44 (Suppl. 1), S105-S111. [CrossRef] [PubMed]

79. Bird, S.P.; Tarpenning, K.M.; Marino, F.E. Liquid carbohydrate/essential amino acid ingestion during a short-term bout of resistance exercise suppresses myofibrillar protein degradation. Metabolism 2006, 55, 570-577. [CrossRef] [PubMed]

80. Bird, S.P.; Tarpenning, K.M.; Marino, F.E. Effects of liquid carbohydrate/essential amino acid ingestion on acute hormonal response during a single bout of resistance exercise in untrained men. Nutrition 2006, 22, 367-375. [CrossRef] 
81. McConell, G.; Kloot, K.; Hargreaves, M. Effect of timing of carbohydrate ingestion on endurance exercise performance. Med. Sci. Sports Exerc. 1996, 28, 1300-1304. [CrossRef]

82. Schweitzer, G.G.; Smith, J.D.; Lecheminant, J.D. Timing carbohydrate beverage intake during prolonged moderate intensity exercise does not affect cycling performance. Int. J. Exerc. Sci. 2009, 2, 4-18.

83. Beelen, M.; Burke, L.M.; Gibala, M.J.; van Loon, L.J. Nutritional strategies to promote postexercise recovery. Int. J. Sport Nutr. Exerc. Metab. 2010, 20, 515-532. [CrossRef]

84. Jentjens, R.; Jeukendrup, A. Determinants of post-exercise glycogen synthesis during short-term recovery. Sports Med. 2003, 33, 117-144. [CrossRef]

85. Hayashi, T.; Wojtaszewski, J.F.; Goodyear, L.J. Exercise regulation of glucose transport in skeletal muscle. Am. J. Physiol. 1997, 273, E1039-E1051. [CrossRef]

86. Goodyear, L.J.; Hirshman, M.F.; King, P.A.; Horton, E.D.; Thompson, C.M.; Horton, E.S. Skeletal muscle plasma membrane glucose transport and glucose transporters after exercise. J. Appl. Physiol. 1990, 68, 193-198. [CrossRef]

87. Burke, L.M. Fueling strategies to optimize performance: Training high or training low? Scand. J. Med. Sci. Sports 2010, 20 (Suppl. 2), 48-58. [CrossRef]

88. Alghannam, A.F.; Gonzalez, J.T.; Betts, J.A. Restoration of muscle glycogen and functional capacity: Role of post-exercise carbohydrate and protein co-ingestion. Nutrients 2018, 10. [CrossRef] [PubMed]

89. van Loon, L.J.; Saris, W.H.; Kruijshoop, M.; Wagenmakers, A.J. Maximizing postexercise muscle glycogen synthesis: Carbohydrate supplementation and the application of amino acid or protein hydrolysate mixtures. Am. J. Clin. Nutr. 2000, 72, 106-111. [CrossRef] [PubMed]

90. Burke, L.M.; Collier, G.R.; Hargreaves, M. Muscle glycogen storage after prolonged exercise: Effect of the glycemic index of carbohydrate feedings. J. Appl. Physiol. 1993, 75, 1019-1023. [CrossRef] [PubMed]

91. Erith, S.; Williams, C.; Stevenson, E.; Chamberlain, S.; Crews, P.; Rushbury, I. The effect of high carbohydrate meals with different glycemic indices on recovery of performance during prolonged intermittent high-intensity shuttle running. Int. J. Sport Nutr. Exerc. Metab. 2006, 16, 393-404. [CrossRef] [PubMed]

92. Stevenson, E.; Williams, C.; McComb, G.; Oram, C. Improved recovery from prolonged exercise following the consumption of low glycemic index carbohydrate meals. Int. J. Sport Nutr. Exerc. Metab. 2005, 15, 333-349. [CrossRef] [PubMed]

93. Brown, L.J.; Midgley, A.W.; Vince, R.V.; Madden, L.A.; McNaughton, L.R. High versus low glycemic index 3-h recovery diets following glycogen-depleting exercise has no effect on subsequent 5-km cycling time trial performance. J. Sci. Med. Sport 2013, 16, 450-454. [CrossRef] [PubMed]

94. Rodriguez, N.R.; DiMarco, N.M.; Langley, S. Position of the American dietetic association, dietitians of Canada, and the American college of sports medicine: Nutrition and athletic performance. J. Am. Diet. Assoc. 2009, 109, 509-527. [CrossRef]

95. Nieman, D.C.; Mitmesser, S.H. Potential impact of nutrition on immune system recovery from heavy exertion: A metabolomics perspective. Nutrients 2017, 9. [CrossRef] [PubMed]

96. Scharhag, J.; Meyer, T.; Auracher, M.; Gabriel, H.H.; Kindermann, W. Effects of graded carbohydrate supplementation on the immune response in cycling. Med. Sci. Sports Exerc. 2006, 38, 286-292. [CrossRef] [PubMed]

97. van Loon, L.J.; Kruijshoop, M.; Verhagen, H.; Saris, W.H.; Wagenmakers, A.J. Ingestion of protein hydrolysate and amino acid-carbohydrate mixtures increases postexercise plasma insulin responses in men. J. Nutr. 2000, 130, 2508-2513. [CrossRef] [PubMed]

98. Kaastra, B.; Manders, R.J.; Van Breda, E.; Kies, A.; Jeukendrup, A.E.; Keizer, H.A.; Kuipers, H.; Van Loon, L.J. Effects of increasing insulin secretion on acute postexercise blood glucose disposal. Med. Sci. Sports Exerc. 2006, 38, 268-275. [CrossRef]

99. Rustad, P.I.; Sailer, M.; Cumming, K.T.; Jeppesen, P.B.; Kolnes, K.J.; Sollie, O.; Franch, J.; Ivy, J.L.; Daniel, H.; Jensen, J. Intake of protein plus carbohydrate during the first two hours after exhaustive cycling improves performance the following day. PLoS ONE 2016, 11, e0153229. [CrossRef]

100. de Oliveira, E.P.; Burini, R.C.; Jeukendrup, A. Gastrointestinal complaints during exercise: Prevalence, etiology, and nutritional recommendations. Sports Med. 2014, 44 (Suppl. 1), S79-S85. [CrossRef]

101. Pedersen, D.J.; Lessard, S.J.; Coffey, V.G.; Churchley, E.G.; Wootton, A.M.; Ng, T.; Watt, M.J.; Hawley, J.A. High rates of muscle glycogen resynthesis after exhaustive exercise when carbohydrate is coingested with caffeine. J. Appl. Physiol. 2008, 105, 7-13. [CrossRef] [PubMed] 
102. Taylor, C.; Higham, D.; Close, G.L.; Morton, J.P. The effect of adding caffeine to postexercise carbohydrate feeding on subsequent high-intensity interval-running capacity compared with carbohydrate alone. Int. J. Sport Nutr. Exerc. Metab. 2011, 21, 410-416. [CrossRef]

103. Hawley, J.A.; Tipton, K.D.; Millard-Stafford, M.L. Promoting training adaptations through nutritional interventions. J. Sports Sci. 2006, 24, 709-721. [CrossRef]

104. Ivy, J.L. Regulation of muscle glycogen repletion, muscle protein synthesis and repair following exercise. J. Sports Sci. Med. 2004, 3, 131-138.

105. Moore, D.R. Maximizing post-exercise anabolism: The case for relative protein intakes. Front. Nutr. 2019, 6, 147. [CrossRef]

106. Witard, O.C.; Jackman, S.R.; Breen, L.; Smith, K.; Selby, A.; Tipton, K.D. Myofibrillar muscle protein synthesis rates subsequent to a meal in response to increasing doses of whey protein at rest and after resistance exercise. Am. J. Clin. Nutr. 2014, 99, 86-95. [CrossRef]

107. Tang, J.E.; Moore, D.R.; Kujbida, G.W.; Tarnopolsky, M.A.; Phillips, S.M. Ingestion of whey hydrolysate, casein, or soy protein isolate: Effects on mixed muscle protein synthesis at rest and following resistance exercise in young men. J. Appl. Physiol. 2009, 107, 987-992. [CrossRef]

108. Rowlands, D.S.; Nelson, A.R.; Phillips, S.M.; Faulkner, J.A.; Clarke, J.; Burd, N.A.; Moore, D.; Stellingwerff, T. Protein-leucine fed dose effects on muscle protein synthesis after endurance exercise. Med. Sci. Sports Exerc. 2015, 47, 547-555. [CrossRef] [PubMed]

109. Macnaughton, L.S.; Wardle, S.L.; Witard, O.C.; McGlory, C.; Hamilton, D.L.; Jeromson, S.; Lawrence, C.E.; Wallis, G.A.; Tipton, K.D. The response of muscle protein synthesis following whole-body resistance exercise is greater following $40 \mathrm{~g}$ than $20 \mathrm{~g}$ of ingested whey protein. Physiol. Rep. 2016, 4, e12893. [CrossRef] [PubMed]

110. Borsheim, E.; Cree, M.G.; Tipton, K.D.; Elliott, T.A.; Aarsland, A.; Wolfe, R.R. Effect of carbohydrate intake on net muscle protein synthesis during recovery from resistance exercise. J. Appl. Physiol. 2004, 96, 674-678. [CrossRef] [PubMed]

111. Roy, B.D.; Tarnopolsky, M.A.; MacDougall, J.D.; Fowles, J.; Yarasheski, K.E. Effect of glucose supplement timing on protein metabolism after resistance training. J. Appl. Physiol. 1997, 82, 1882-1888. [CrossRef] [PubMed]

112. Nelson, A.R.; Phillips, S.M.; Stellingwerff, T.; Rezzi, S.; Bruce, S.J.; Breton, I.; Thorimbert, A.; Guy, P.A.; Clarke, J.; Broadbent, S.; et al. A protein-leucine supplement increases branched-chain amino acid and nitrogen turnover but not performance. Med. Sci. Sports Exerc. 2012, 44, 57-68. [CrossRef] [PubMed]

113. Di Donato, D.M.; West, D.W.; Churchward-Venne, T.A.; Breen, L.; Baker, S.K.; Phillips, S.M. Influence of aerobic exercise intensity on myofibrillar and mitochondrial protein synthesis in young men during early and late postexercise recovery. Am. J. Physiol. Endocrinol. Metab. 2014, 306, E1025-E1032. [CrossRef]

114. Phillips, S.M.; Tipton, K.D.; Aarsland, A.; Wolf, S.E.; Wolfe, R.R. Mixed muscle protein synthesis and breakdown after resistance exercise in humans. Am. J. Physiol. 1997, 273, 99-107. [CrossRef]

115. Gabel, K.; Hoddy, K.K.; Haggerty, N.; Song, J.; Kroeger, C.M.; Trepanowski, J.F.; Panda, S.; Varady, K.A. Effects of 8-hour time restricted feeding on body weight and metabolic disease risk factors in obese adults: A pilot study. Nutr. Healthy Aging 2018, 4, 345-353. [CrossRef]

116. Tinsley, G.M.; Moore, M.L.; Graybeal, A.J.; Paoli, A.; Kim, Y.; Gonzales, J.U.; Harry, J.R.; VanDusseldorp, T.A.; Kennedy, D.N.; Cruz, M.R. Time-restricted feeding plus resistance training in active females: A randomized trial. Am. J. Clin. Nutr. 2019, 110, 628-640. [CrossRef] [PubMed]

117. Aird, T.P.; Davies, R.W.; Carson, B.P. Effects of fasted vs fed-state exercise on performance and post-exercise metabolism: A systematic review and meta-analysis. Scand. J. Med. Sci. Sports 2018, 28, 1476-1493. [CrossRef] [PubMed]

118. Clayton, D.J.; James, L.J. The effect of breakfast on appetite regulation, energy balance and exercise performance. Proc. Nutr. Soc. 2016, 75, 319-327. [CrossRef] [PubMed]

119. Clayton, D.J.; Barutcu, A.; Machin, C.; Stensel, D.J.; James, L.J. Effect of breakfast omission on energy intake and evening exercise performance. Med. Sci. Sports Exerc. 2015, 47, 2645-2652. [CrossRef] [PubMed]

120. Arciero, P.J.; Baur, D.; Connelly, S.; Ormsbee, M.J. Timed-daily ingestion of whey protein and exercise training reduces visceral adipose tissue mass and improves insulin resistance: The PRISE study. J. Appl. Physiol 2014, 117, 1-10. [CrossRef] [PubMed] 
121. Arciero, P.J.; Edmonds, R.; He, F.; Ward, E.; Gumpricht, E.; Mohr, A.; Ormsbee, M.J.; Astrup, A. Protein-pacing caloric-restriction enhances body composition similarly in obese men and women during weight loss and sustains efficacy during long-term weight maintenance. Nutrients 2016, 8. [CrossRef] [PubMed]

122. Arciero, P.J.; Edmonds, R.C.; Bunsawat, K.; Gentile, C.L.; Ketcham, C.; Darin, C.; Renna, M.; Zheng, Q.; Zhang, J.Z.; Ormsbee, M.J. Protein-pacing from food or supplementation improves physical performance in overweight men and women: The PRISE 2 study. Nutrients 2016, 8. [CrossRef]

123. Arciero, P.J.; Ives, S.J.; Norton, C.; Escudero, D.; Minicucci, O.; O’Brien, G.; Paul, M.; Ormsbee, M.J.; Miller, V.; Sheridan, C.; et al. Protein-pacing and multi-component exercise training improves physical performance outcomes in exercise-trained women: The PRISE 3 study. Nutrients 2016, 8, 332. [CrossRef] [PubMed]

124. Mamerow, M.M.; Mettler, J.A.; English, K.L.; Casperson, S.L.; Arentson-Lantz, E.; Sheffield-Moore, M.; Layman, D.K.; Paddon-Jones, D. Dietary protein distribution positively influences 24-h muscle protein synthesis in healthy adults. J. Nutr. 2014, 144, 876-880. [CrossRef]

125. Arciero, P.J.; Ormsbee, M.J.; Gentile, C.L.; Nindl, B.C.; Brestoff, J.R.; Ruby, M. Increased protein intake and meal frequency reduces abdominal fat during energy balance and energy deficit. Obesity 2013, 21, 1357-1366. [CrossRef]

126. Trommelen, J.; van Loon, L.J. Pre-sleep protein ingestion to improve the skeletal muscle adaptive response to exercise training. Nutrients 2016, 8. [CrossRef] [PubMed]

127. Snijders, T.; Res, P.T.; Smeets, J.S.; van Vliet, S.; van Kranenburg, J.; Maase, K.; Kies, A.K.; Verdijk, L.B.; van Loon, L.J. Protein ingestion before sleep increases muscle mass and strength gains during prolonged resistance-type exercise training in healthy young men. J. Nutr. 2015, 145, 1178-1184. [CrossRef] [PubMed]

128. Ormsbee, M.J.; Gorman, K.A.; Miller, E.A.; Baur, D.A.; Eckel, L.A.; Contreras, R.J.; Panton, L.B.; Spicer, M.T. Nighttime feeding likely alters morning metabolism but not exercise performance in female athletes. Appl. Physiol. Nutr. Me. 2016, 41, 719-727. [CrossRef] [PubMed]

129. Antonio, J.; Ellerbroek, A.; Peacock, C.; Silver, T. Casein protein supplementation in trained men and women: Morning versus evening. Int. J. Exerc. Sci. 2017, 10, 479-486.

130. Shukla, A.P.; Iliescu, R.G.; Thomas, C.E.; Aronne, L.J. Food order has a significant impact on postprandial glucose and insulin levels. Diabetes Care 2015, 38, e98-e99. [CrossRef] [PubMed]

131. Knuiman, P.; Hopman, M.T.; Mensink, M. Glycogen availability and skeletal muscle adaptations with endurance and resistance exercise. Nutr. Metab. 2015, 12, 59. [CrossRef]

132. Impey, S.G.; Hearris, M.A.; Hammond, K.M.; Bartlett, J.D.; Louis, J.; Close, G.L.; Morton, J.P. Fuel for the work required: A theoretical framework for carbohydrate periodization and the glycogen threshold hypothesis. Sports Med. 2018, 48, 1031-1048. [CrossRef]

133. Marquet, L.A.; Brisswalter, J.; Louis, J.; Tiollier, E.; Burke, L.M.; Hawley, J.A.; Hausswirth, C. Enhanced endurance performance by periodization of carbohydrate intake: "Sleep Low" strategy. Med. Sci. Sports Exerc. 2016, 48, 663-672. [CrossRef]

134. Marquet, L.A.; Hausswirth, C.; Molle, O.; Hawley, J.A.; Burke, L.M.; Tiollier, E.; Brisswalter, J. Periodization of carbohydrate intake: Short-term effect on performance. Nutrients 2016, 8. [CrossRef]

135. Mitchell, C.J.; Gatta, P.A.D.; Petersen, A.C.; Cameron-Smith, D.; Markworth, J.F. Soy protein ingestion results in less prolonged p70S6 kinase phosphorylation compared to whey protein after resistance exercise in older men. J. Int. Soc. Sport Nutr. 2015, 12, 6. [CrossRef]

(C) 2020 by the authors. Licensee MDPI, Basel, Switzerland. This article is an open access article distributed under the terms and conditions of the Creative Commons Attribution (CC BY) license (http://creativecommons.org/licenses/by/4.0/). 